Article

\title{
Impacts of Climate Change on the Eastern Mediterranean and the Middle East and North Africa Region and the Water-Energy Nexus
}

\author{
Manfred A. Lange \\ Energy, Environment and Water Research Center, The Cyprus Institute; P.O. Box 27456, CY1645 Nicosia, Cyprus; \\ m.a.lange@cyi.ac.cy; Tel.: +357-22-208-621
}

Received: 27 May 2019; Accepted: 10 July 2019; Published: 9 August 2019

check for updates

\begin{abstract}
The present paper aims to elucidate impacts of climate change on the availability and security of water and energy in the Middle East and North Africa region (MENA region; including the Eastern Mediterranean) in the context of the water-energy nexus. It largely builds on existing knowledge and understanding and aims to present a review of existing information on this topic. The region is particularly challenged by a number of factors, including the large variability of bio-geographical characteristics, extreme population growth over the last few decades, and substantial societal and economical transitions, as well as armed conflicts in some of the countries in the region. Anticipated changes in climate conditions will exacerbate the challenges regarding water and energy security in the region. Major impacts of climate change include a significant increase in summer temperatures, which will lead to a growing number of heat waves, primarily in urban structures. A general decrease in precipitation in many of the MENA countries is foreseen, resulting in enhanced droughts and a growing number of dry spells. In addressing energy and water scarcities and their mutual interrelationships, an integrated water-energy nexus concept offers promising prospects to improve environmental, climate, human, and political security. However, only very few countries in the MENA region have presently implemented such a concept. Mitigation and adaptation strategies addressing water and energy scarcity include enhanced efficiency of resource use, integrated technology assessments regarding electricity generation, and a stronger reliance on renewable/solar technologies. While looking at the MENA region as a whole, some emphasis will be given to Cyprus and the Eastern Mediterranean.
\end{abstract}

Keywords: water-energy nexus; MENA region; climate change; mitigation/adaptation strategies; renewable/solar energy technologies

\section{Introduction}

Life on Earth depends critically on the availability of water and energy in various forms. It is essential to understand that both quantities are closely connected and mutually dependent. This is particularly relevant for industrially generated energy sources and water for human consumption. The generation of conventional energy in hydrocarbon-fired power plants and nuclear energy installations require water for cooling, whereas the pumping of water from underground aquifers, water treatment, and its transport in distribution networks requires significant amounts of energy [1,2]. In addition, the availability of water plays a key role in the agriculture and food sector and is one of the determining factors for food security in many countries of the world. The anticipated changes in climatic conditions, notably the enhanced warming in urban settings (known as "urban heat island effect"; see below) will need substantial quantities of electricity for space cooling to maintain comfortable indoor conditions.

Due to an enhanced demand for basic natural resources and basic commodities as a probable result of global population increase and changes in lifestyle, the sufficient provision of water, energy, 
and food to communities in many parts of the world is increasingly seen as an interconnected challenge. This has been called the water-energy-food nexus [3], which is subject to numerous investigations. Other drivers of the nexus comprise the reduction of ecosystem services because of overexploitation and the continuous growth of urban conglomerates. The latter leads to additional environmental degradation resulting from an ever growing volume of human-derived waste that releases various contaminants into terrestrial and marine ecosystems see, e.g., [4,5]. An increasing trend of globally linked private-sector economic activities ("globalization") has enhanced the tendencies to externalize resource exploitation and has resulted in the deterioration of environmental integrity in many regions of the world. This, in turn, has exacerbated the challenges to water, energy, and food security in these regions [for more background and information, see, e.g., [6-8].

The anticipated changes in climatic conditions on global, regional, and local scales represent challenges of a particularly severe nature (see, e.g., [9] and below). In order to minimize their adverse consequences, effective and societally acceptable mitigation and adaptation strategies and related concrete measures have to be developed and implemented. The inherent feedback and interdependencies between the individual elements of the climate system may lead to the exceedance of critical thresholds and tipping points. Such a development will significantly challenge water, energy, and food security in many parts of the world, not least in the Middle East and North Africa Region (MENA region) and the Eastern Mediterranean (from here on, the term MENA region is meant to include the Eastern Mediterranean, without explicit mentioning) see, e.g., [10,11].

While these issues are relevant on a global scale, this paper focusses more on a part of the world that may face some of the challenges mentioned above at higher intensities. More specifically, this paper aims to address the following questions:

- What are the major characteristics of and challenges faced by the MENA region that also distinguish it from the rest of the world?

- To what extent do changes in climatic conditions and their impacts exacerbate these challenges, with a particular focus on urban structures?

- How can these challenges be seen and understood in the context of the water-energy nexus?

- What are some promising mitigation and adaptation strategies and measures that may reduce adverse effects of climate change in the MENA region based on a water-energy nexus concept?

This paper is not intended to primarily present new research, but rather to give a concise overview of important and relevant ramifications of climate change for the water-energy nexus for the MENA region, in general, and for Cyprus in particular. In so doing, I have relied mainly on existing literature and published information as well as on my own expertise in some of the issues treated. Given the breadth and scope of the subjects covered in this paper, I do not claim to provide a completely comprehensive overview over all relevant facts. This notwithstanding, I trust that the reader will still benefit from the material provided and from the conclusions drawn.

\section{The MENA Region: Major Characteristics and Challenges}

The region encompassing countries of the eastern Mediterranean, the Middle East, and North Africa, which is called the MENA region, is a region full of a varied history and a rich cultural heritage. While no unambiguous definitions exist, the following countries (in alphabetical order) are usually considered to belong to the MENA region (Figure 1): Algeria, Bahrain, Djibouti, the Arab Republic of Egypt, the Islamic Republic of Iran, Iraq, Israel, Jordan, Kuwait, Lebanon, Libya, Morocco, Oman, Qatar, Saudi Arabia, the Syrian Arab Republic, Tunisia, the United Arab Emirates, West Bank and Gaza, and the Republic of Yemen [12]. In providing this definition, we have no intentions to violate or reintroduce any political or other stipulations and/or to introduce any "hierarchy" or order with regard to MENA countries. 


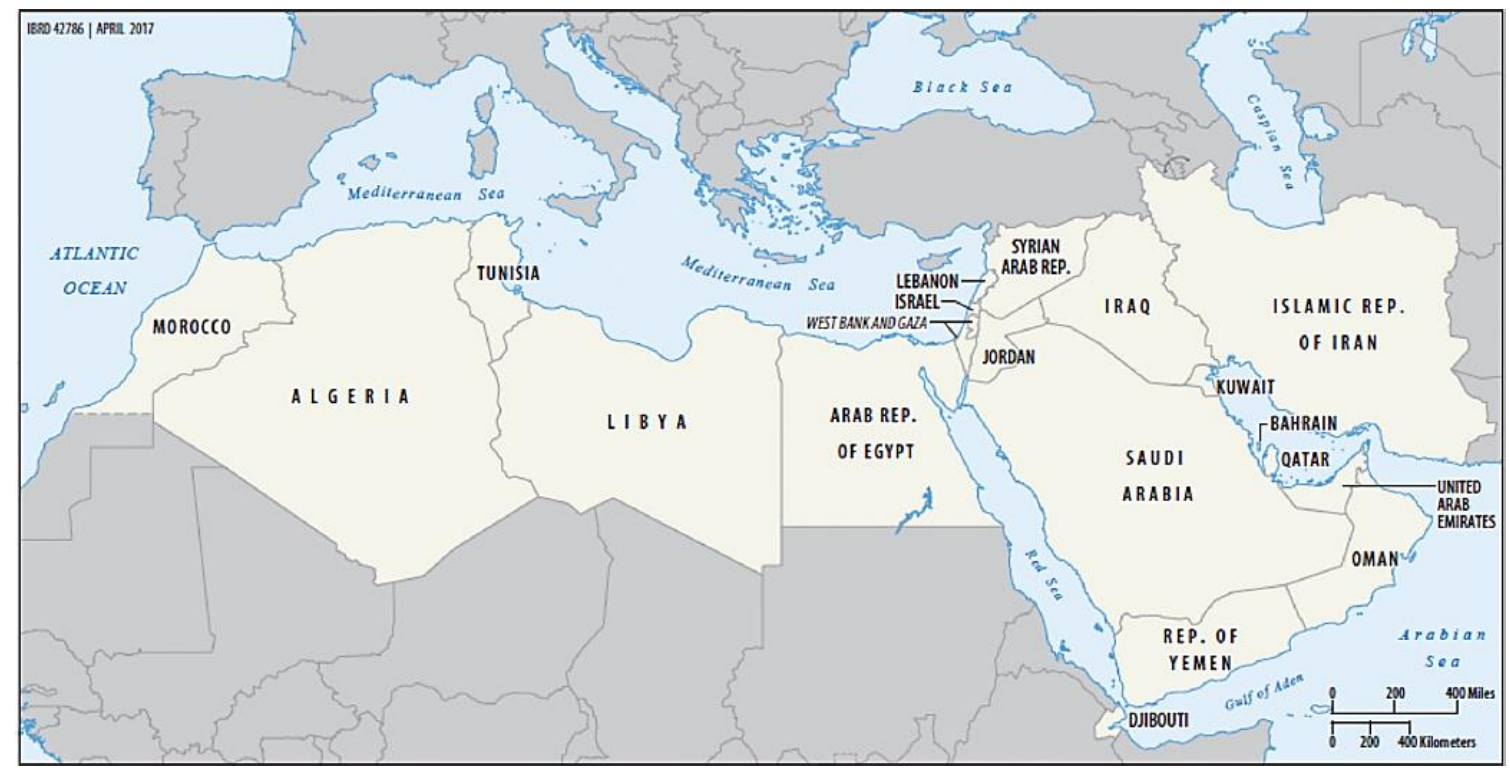

Figure 1. Map of the Middle East and North Africa (MENA) region; source: [12].

The MENA region is expected to experience future climatic changes above the global means. Thus, the region has been classified as one of the Earth's climate change "hot-spots" [13]. Extreme climate conditions will have significant consequences for water and energy security in at least parts of the MENA region (see below).

The region is characterized by stark environmental gradients, as well as by differences in the provision of ecosystem services, both East to West and South to North. In addition, the region is characterized by significant differences in the political, economic, societal, ideological, and religious settings in each of the MENA countries. Driven largely by varying degrees of natural resource availabilities, some of the countries (particularly those on the Arabic Peninsula), provide sufficient economic prospects to their citizens, while in others, a large proportion of the population has to endure significant economic hardships. These differences are reflected in the availability and pricing of water and energy to MENA communities.

The events of the "Arab Spring", also called "Arabellion", which started in 2010, have resulted in major political, economic, and societal transitions and have frequently been accompanied by significant armed struggles within and between countries of the MENA region. This has not only caused hardships on the local population, the demolishing of valuable infrastructure, and the obliteration of administrative and governance structures, but has also led to the loss of energy and water resources to be accessed by individuals and communities. These developments and the still ongoing armed conflicts in parts of the region (particularly in Iraq, Libya, Syria, and Yemen) render this region one of the global political, military, and humanitarian "hot-spots" (for more background, please see: [14-16].)

The MENA region has experienced one of the fastest growths in population worldwide. From about 110 million inhabitants in the 1950s, the MENA population has grown to 569 million in 2017 [17]. Regardless of generally declining rates of fertility, absolute population numbers are expected to further double to about 1.1 billion inhabitants by 2100 , according to medium variant projections (Figure 2), and will be higher than China's population, whose population is expected to continue to shrink to just over 1 billion [17].

Two countries contribute the most to population growth in the MENA region: Egypt and Iraq. In 2100, they will account for total populations of 199 million and 156 million inhabitants, respectively [18]; in the cited study, Sudan with a projected population of 137 million is also mentioned, but omitted here since the Sudan lies outside the MENA Region)]. It is obvious that such growth in population requires the increased provision of basic resources. This proves particularly difficult in some of the MENA countries that are currently resource-poor but labor-abundant, i.e., that lack sufficient 
water (and food) resources, but are home to large populations (e.g., Egypt and Palestine/Gaza). Thus, absolute population growth will mean more water and energy demands. While the MENA region has a formidable renewable energy potential, its significant wind and, in particular, solar power potentials, however, remain largely under-utilized (see below).

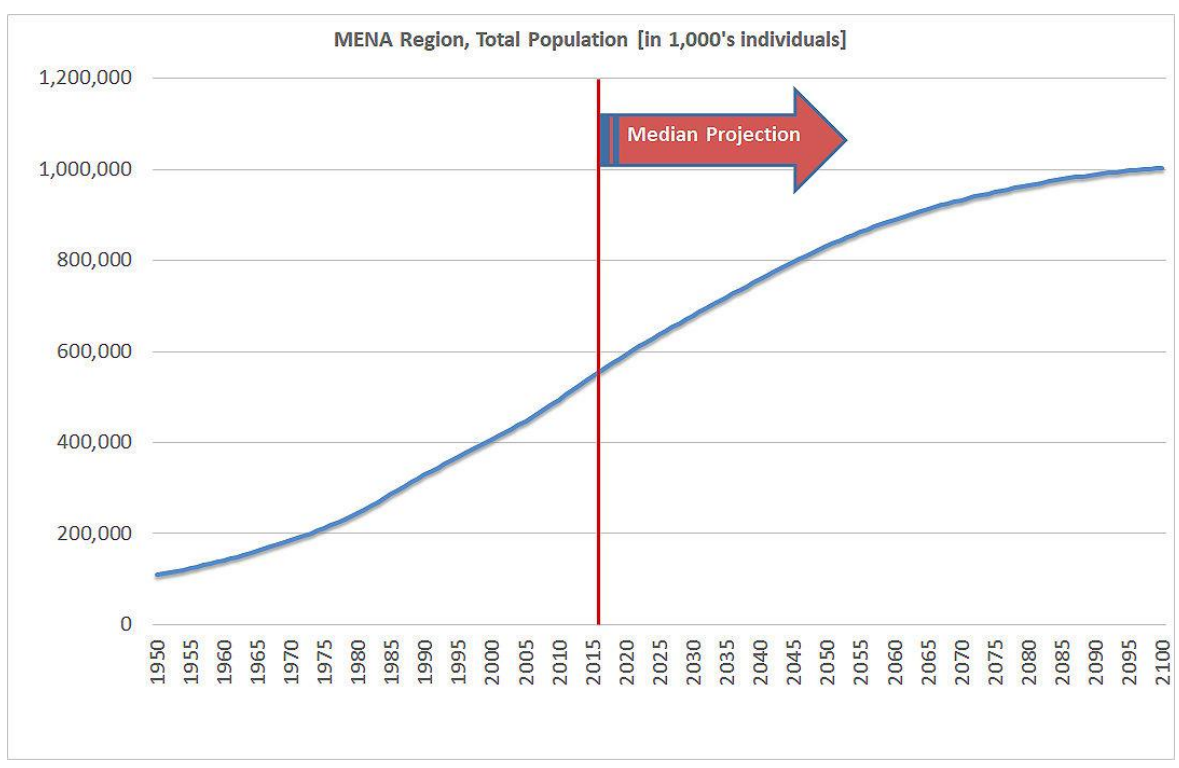

Figure 2. Population development of MENA countries; total population (both sexes combined) annually for 1950-2100 (estimates: 2015-2100); this figure has been developed based on data by [17].

Finally, the MENA region is one of the most urbanized regions globally. Moreover, the highest population densities and the location of major cities are largely concentrated along the coast of the Mediterranean (Figure 3). This increases risks to habitability of a number of these cities and sub-regions (e.g., the Nile Delta) in the foreseeable future due to sea level rise.

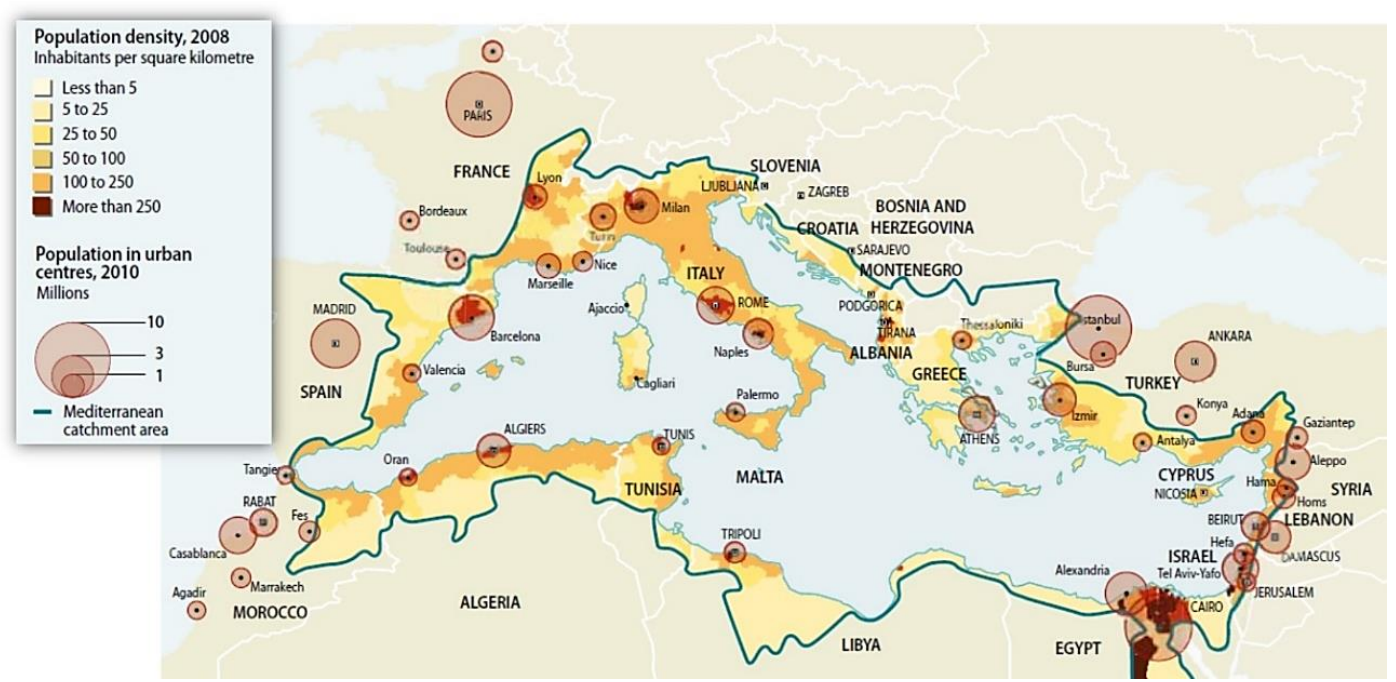

Figure 3. Population densities of Mediterranean countries, including Mediterranean MENA countries; source [19].

To consider expected future developments of urban dwellings, the urban population of the Arab states has quadrupled between 1970 and 2010 and is expected to more than double over the next 40 years [20]. 


\section{Climate Change in the MENA Region}

\subsection{Regional Changes in Temperature and Precipitation}

As mentioned earlier, climate changes in the Mediterranean Basin are anticipated to significantly exceed global mean values [13]. Given current projections, this will equally apply to most of the other MENA countries and countries of southwest Asia, and will be associated with increases in the frequency and intensity of droughts and hot weather conditions [21,22]. In order to derive detailed information at higher spatial resolutions, global climate model results are being utilized as boundary conditions for regional climate models e.g., [23-25]. Such studies enable a more rigorous assessment of the impacts of these changes, e.g., with regard to sub-regional to local temperature extremes or changes in precipitation. The PRECIS regional climate model (Providing REgional Climates for Impacts Studies) was developed at the Hadley Centre at the UK Met Office. PRECIS can be applied to any area of the globe to generate detailed climate change projections [26].

When considering regional climate modeling results pertaining to expected temperature changes in the MENA region (Figure 4; $[11,27]$ ), a number of conclusions can be drawn. While the western MENA countries of North Africa are not covered in the models shown here, results for the wider MENA region are consistent with the results shown here [25].

- Changes in summer temperatures lie uniformly above those seen for the winter months, which are seen to be more spatially uniform;

- The increases in temperature for the 2070-2099 $\left(3.5-7^{\circ} \mathrm{C}\right)$ time slots are significantly higher than for the mid-century period (2040-2069: $\left.3-5^{\circ} \mathrm{C}\right)$;

- The largest temperature rises are expected for countries in the northeastern Mediterranean at latitudes north of $36^{\circ}-38^{\circ} \mathrm{N}$ across the Balkan Peninsula and Turkey.

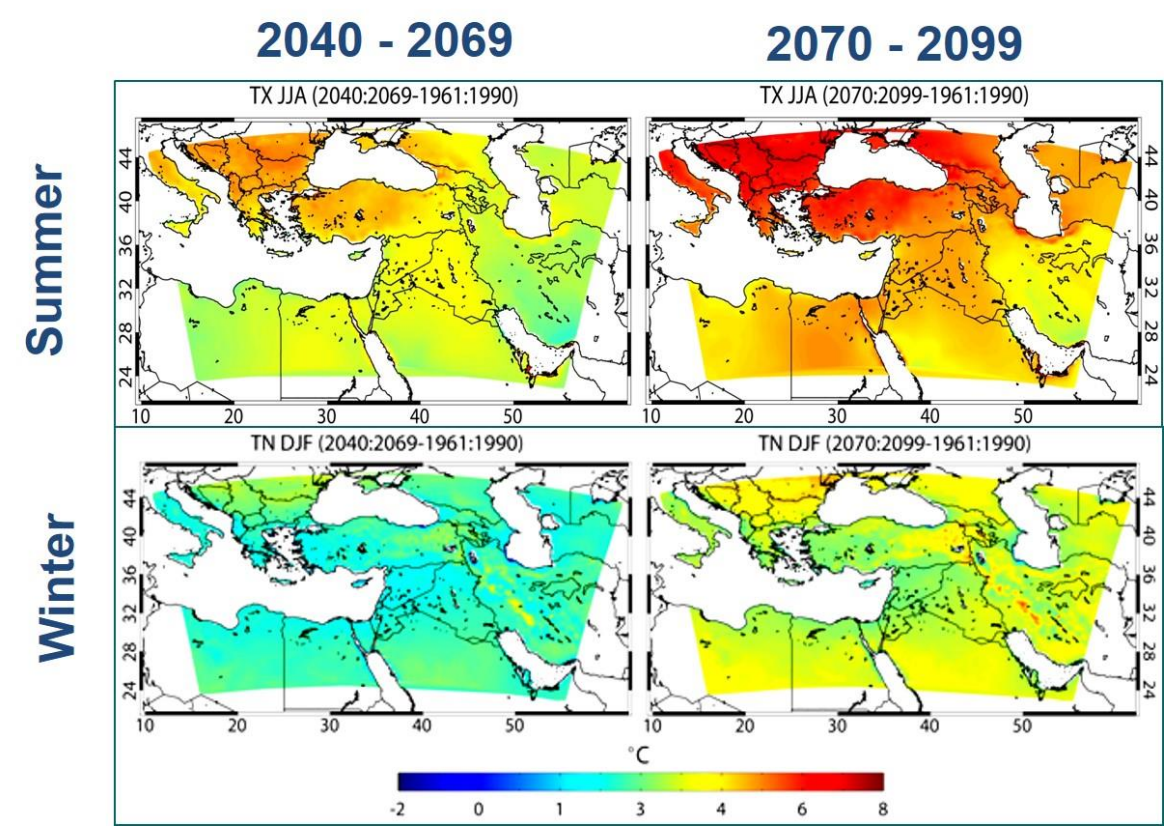

Figure 4. Patterns of changing mean summer maximum (JJA = June, July, August) and mean winter minimum (DJF = December, January, February) temperatures, TX (top) and TN (bottom), respectively, calculated from Providing REgional Climates for Impacts Studies (PRECIS) output. The left panels show projected mean changes in the temperature maximum (TX) and nighttime temperature minimum (TN) for 2040-2069 and the right panels for 2070-2099 relative to the 1961-1990 control period; modified after [11]. 
As to the latter observation, it has recently been demonstrated that enhanced warming over parts of the Mediterranean Basin will lead to increased evaporation and decreasing soil moisture content. The temperature increase may subsequently be amplified by the depletion of soil moisture, which limits evaporative cooling. These processes constitute a positive soil moisture-atmosphere/temperature feedback [28].

According to newer publications [27,29], in situ observations covering the recent past indicate consistently an increase in heat extremes in the MENA region, whereas climate model results project a continuation of this trend and further rising mean temperatures until the end of the 21st century. This implies that the number of heat waves, i.e., a prolonged period of more than five hot days and warm nights, may increase significantly over the coming decades. While the average maximum temperatures during the hottest days in the recent past were about $43^{\circ} \mathrm{C}$, they may increase to about $46^{\circ} \mathrm{C}$ by the middle of the century and reach almost $50{ }^{\circ} \mathrm{C}$ by the end of the century [27].

Projections of changes in the precipitation regime of the MENA region, derived from regional climate models [11,30], are less robust. This notwithstanding, the overall trend of decreasing precipitation over most of the MENA region (Figure 5) is consistent with global climate model results and other regional climate modeling [21,25].

\section{$2040-2069 \quad 2070-2099$}

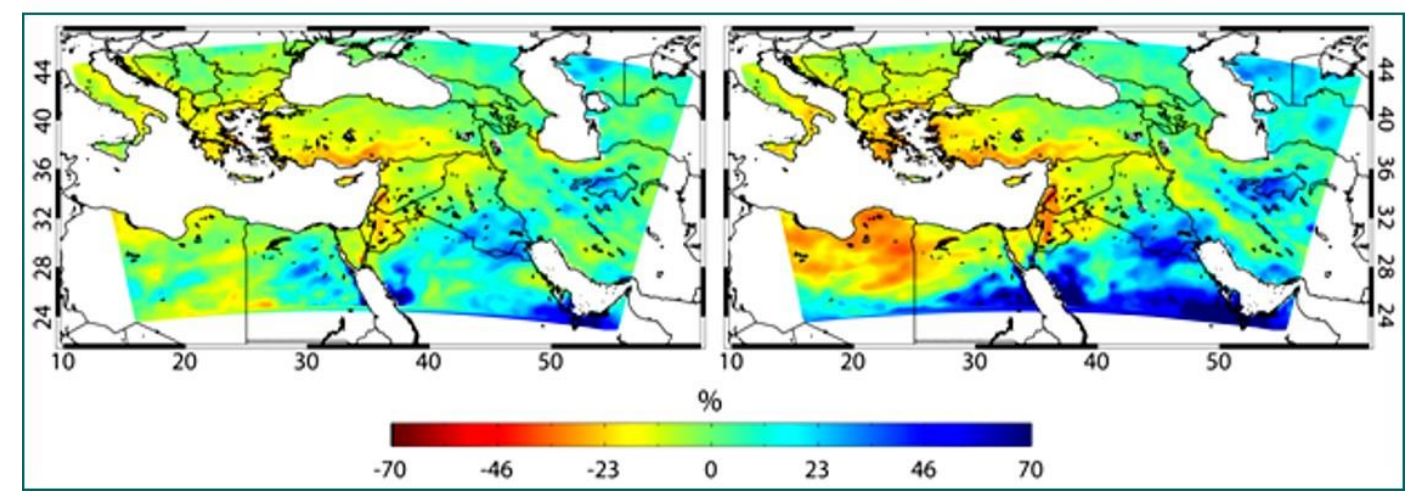

Figure 5. Patterns of changing annual mean precipitation, from PRECIS output for 2040-2069 (left panel) and for 2070-2099 (right panel) relative to the control period 1961-1990; source: Lelieveld, pers. comm.

As can be seen in Figure 5, towards 2040-2069, precipitation over much of the MENA region will have decreased by about 10-20\% relative to the 1961-1990 period. The apparent precipitation increase projected for Bahrain, Kuwait, and Qatar exceeds 30\%, but since absolute amounts are extremely small, these changes are considered insignificant. While many of the countries are expected to see reductions in annual mean precipitation by about $10 \%$, both Cyprus and Lebanon will have a decrease in precipitation in excess of $20 \%$. Even though precipitation will continue to decline until the end of the century, the overall decrease will be only moderately larger relative to mid-century for most of the region ([11]).

Specific impacts of climate change on water availability and water security in the MENA region include:

- a lengthening of the dry season for most MENA countries;

- a 30-70\% reduction in recharge of aquifers in the Mediterranean Coast, impacting the quantity and quality of ground water [31];

- significant reductions in surface and subsurface water availability directly affecting river flow, instream flow, and the soil water reservoirs; the latter will have adverse consequences on food production and food security, adding to pressure on groundwater aquifers and surface water reservoirs in MENA countries [32]; 
- in Jordan, available water resources are expected to fall below the $50 \mathrm{~m}^{3}$ per capita/year threshold, which has been identified as the minimum amount required for social and economic development [33].

These impacts will require well-considered adaptation strategies, for instance, alternative freshwater sources such as desalination, to meet basic needs (see below).

\subsection{Enhanced Warming in Urban Structures}

Following the UN's World Urbanization Prospect Report of 2014, 54\% of the world's population now live in metropolitan areas [34]. By 2050, this percentage will increase to $86 \%$ in advanced countries, and $64 \%$ in developing nations. In line with these developments, the MENA region has seen and will continue to experience an accelerating trend of urbanization see, e.g., [20].

With regard to temperature regimes, cities experience what has been called the "urban heat island effect" e.g., [35-37], comprising an enhanced heat accumulation within the urban area due to buildings, transportation infrastructure, and human activities. The heat accumulations lead to temperature increases within the city limits that are $2-3{ }^{\circ} \mathrm{C}$ higher than the surrounding rural areas. Reduced ventilation within cities exacerbates the warming, particularly during summer heat waves. Heat waves can have profound impacts on human health, resulting in excess mortality, which is greatest among the elderly and people suffering illnesses [11]. The often observed deteriorating air quality in cities in combination with extreme heat will exacerbate human health risks in urban structures [11].

Results of regional climate models interpolated to the areas of major cities in the MENA region have confirmed the expected enhanced warming trend of cities relative to the rest of each country [29]. Figure 6 indicates that the coolest summer months (i.e., during June, July, and August) for the 2070-2099 time window are warmer than the hottest summer months of the recent past (1961-1990). A study by Pal and Eltahir [22] confirms these results for cities in southwest Asia, i.e., the Arabian Peninsula and western Iran. Their results suggest that extremes of wet-bulb temperatures in this region are likely to approach and exceed critical threshold in the dry-bulb temperature of $35^{\circ} \mathrm{C}$. The computations are based on an ensemble of high-resolution regional climate model simulations and have been carried out under a business-as-usual scenario of future greenhouse gas concentrations [22]. Thus, we are expecting a major shift in summer temperatures and extreme heat in urban structures. Aside from the already mentioned human health risks, this also implies impacts on the water and energy sector.

As to the water sector, the aforementioned decreases in precipitation will reduce available drinking water for city inhabitants and green spaces. Unless unconventional sources can be utilized (e.g., desalination with repercussions on the energy sector, see below), extreme scarcity and water rationings can be anticipated.

With regard to the energy sector, the indicated increase in urban heat waves during the summer months implies additional electricity demand for space cooling in private, commercial, and public buildings in order to maintain comfortable/required indoor conditions. The resultant peak in electricity demand for the summer months is well documented, e.g., for Cyprus [39]. 


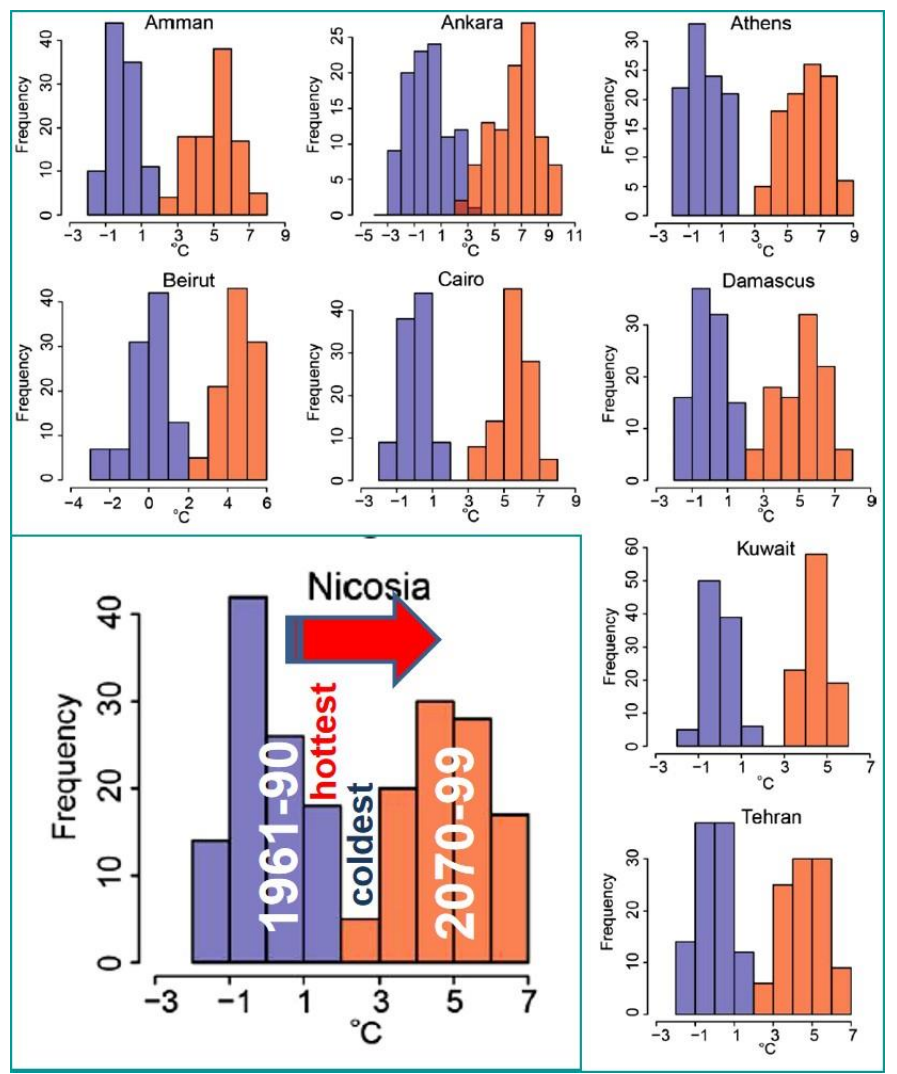

Figure 6. Recent and end-of-century temperature anomalies for a number of MENA and eastern Mediterranean country capitals. Model calculated frequency histograms (\%) of daytime maximum summer (JJA = June, July, August) temperature deviations from the three-months-mean, relative to the period 1961-1990, based on the A1B scenario. Blue is for the period 1961-1990 (hence centered around $0{ }^{\circ} \mathrm{C}$ ) and red for the period 2070-2099; the large insert illustrates the major characteristics of the observed warming trend for Nicosia; adapted and modified from $[29,38]$.

\section{The Water-Energy Nexus}

The characteristics and various details of the water-energy nexus (WEN) in general, and in the context of the MENA region in particular, has been addressed by several authors [1,2,32,40-45]. It has been shown that issues of scarcity and resource security for water and energy are often interrelated and mutually dependent and are best tackled by considering them jointly and holistically. In the following, I will therefore provide a brief introduction to the WEN and will subsequently provide some insights into WEN characteristics in the MENA region.

\subsection{Basic Understanding of the Water-Energy Nexus}

When looking at the WEN in general, one usually starts by assessing the role of water in the energy sector and that of energy in the water sector. Thus, when appraising the provision of potable water to end users from conventional sources (i.e., excluding desalination), the energy needs for various processes comprise energy for:

- conveyance and pumping;

- water treatment;

- water pumping;

- wastewater treatment;

- $\quad$ and for constructing, operating, and maintaining water-supply facilities. 
The energy needs for unconventional water sources, specifically for seawater desalination, will be even higher (see below).

Conversely, water is needed in the energy sector for a number of important processes, including:

- $\quad$ water for the extraction and refinement of natural resources;

- more specifically, water in mining and quarrying operations;

- water for hydrocarbon extraction and refining;

- and water for the cooling of conventional power plants, including nuclear power plants;

- in addition, water provides the source of energy in hydroelectric power plants.

These more general relationships between water and energy manifest themselves to a different extent, when considering regional, national, or even local scales.

\subsection{The Water-Energy Nexus in the MENA region}

Economic development, population growth, changes in lifestyle, and shifting consumption patterns, as well as high inefficiencies that result from technical and managerial inadequacies, on the one hand, and energy and water subsidies in several countries of the region, on the other, are drivers for the increasing demand for water and energy in the MENA region. Because of the already mentioned interrelationships between these two commodities and their provision, an analysis in the context of the water-energy nexus is particularly advisable in the MENA countries. While looking at the energy and water sectors separately, the following sections readily illustrate their interdependencies and interrelationships.

\subsubsection{The Energy Sector}

As outlined above, prolonged and enhanced heat waves in the MENA region will lead to additional energy consumption in urban settings, primarily for space cooling [46-48]. In order to satisfy rising freshwater demands, electricity consumption by conventional seawater desalination represents an equally important energy need in the MENA region

In order to satisfy the rising energy and electricity demand, the construction of additional electricity generation facilities is urgently needed. This has led to the installation of new electricity generation capacities in the Middle East. As outlined by the current policy scenario of the World Energy Outlook 2016, the capacity of new power generation facilities in Gulf Cooperation Council (GCC) countries is projected to increase by $294 \mathrm{GW}$ between 2014 to 2040 . This represents a more than doubling of the currently installed capacity of 285 GW in 2014 [49]. However, such an expansion does not only entail significant capital investments by state authorities and the private sector in the coming years (possibly through newly formed private-public partnerships). It also requires the application of holistic assessment approaches for decisions about electricity generation technologies to be employed. In particular, the replacement of conventional power generation technologies by renewable technologies appears to be a viable alternative (see below). In the context of the WEN, the consumption of water in power plants varies widely among different electricity generation technologies. It should be noted that renewable technologies have a clear advantage over conventional (hydrocarbon-driven) technologies by being less water demanding [41].

\subsubsection{The Water Sector}

As outlined above, currently increasing deficiencies in water availability in the MENA region are largely due to rising temperatures and declining precipitation in the recent past. It is likely that this trend will increase with progress in climate change. Today, the MENA region is not only one of the world's most water-scarce regions on the global scale, but several countries in the region face already severe water stress [50]. As has been shown, MENA countries with high population numbers will also have the highest gaps in available water under average scenarios of future climate change. Consequently, the total unmet water demand in the MENA region is expected to amount to $199 \mathrm{~km}^{3}$ [50]. 
MENA countries with crude oil and gas production, i.e., Iraq, Iran, Egypt, and Saudi Arabia, face particularly high water demand gaps. As mentioned before, this is also because hydrocarbon extraction and refining requires substantial amounts of water.

\subsubsection{Water-Energy Interrelationship/Interdependencies}

As a remedy to the increasing demand for potable water in the foreseeable future, the energy-intensive desalination of seawater is going to play a key role in the water supply system of MENA countries. In fact, potable/drinking water and industrial water consumption are the drivers for the very high reliance on seawater desalination across the MENA region. Desalination is already employed heavily in some of the MENA countries (Figure 7). While the Gulf States, Israel, and Cyprus (not shown here) stand out, the desalination capacity of the Middle East and North Africa amounts to $46.7 \%$ of the global desalination capacity [12].

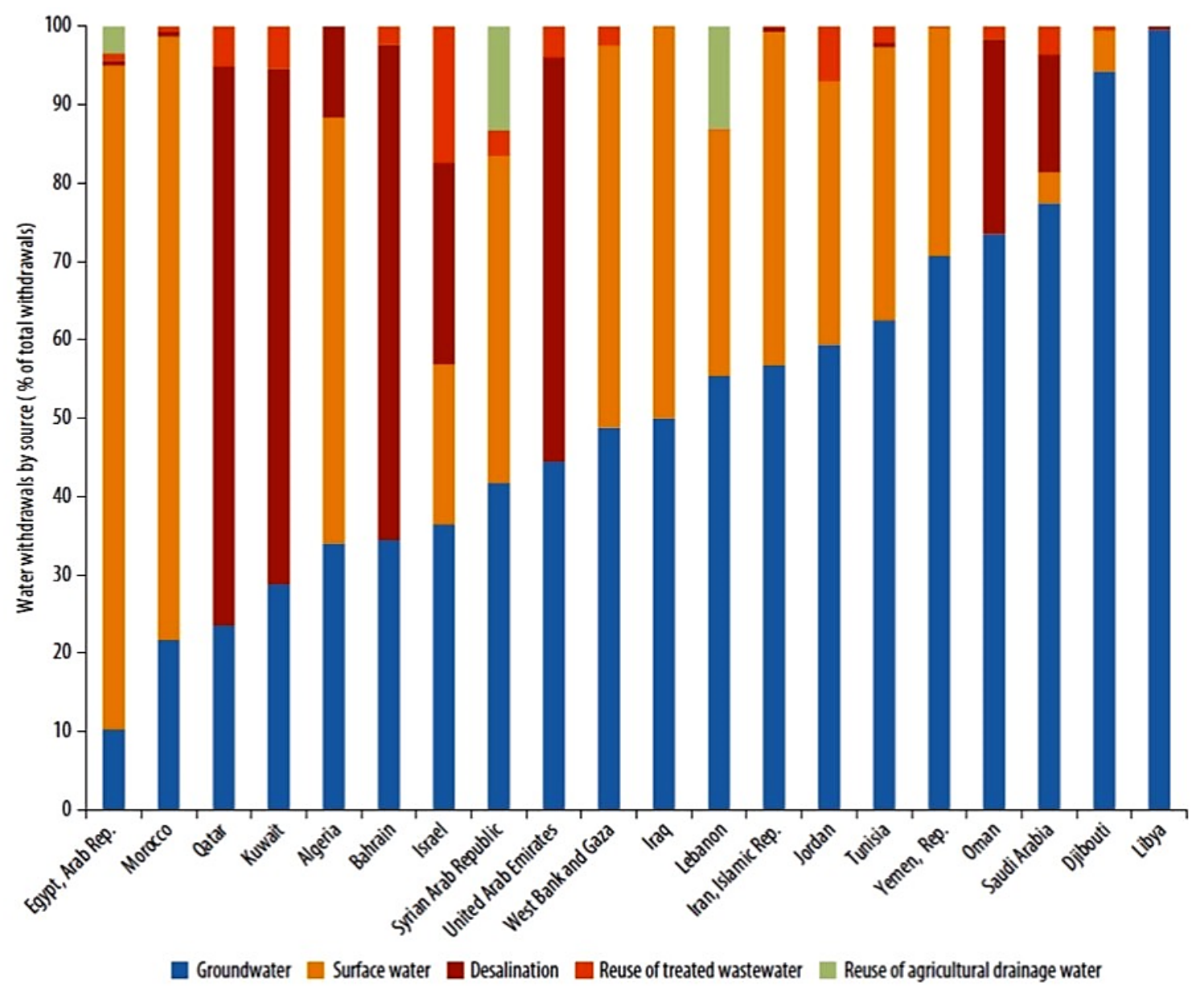

Figure 7. Water withdrawals in MENA countries, by source, as a percentage of total withdrawals, by country and economy, 2010; source: [12].

Desalination is a highly energy-intensive technology. Consequently, the costs of potable water produced by desalination are strongly correlated with energy consumption and energy prices [51]. It has been shown that an average of $12 \%$ of total sector fuel consumption across the countries of the Gulf Cooperation Council (GCC) is spent on desalination, ranging from 10\% in Saudi Arabia to approximately $30 \%$ in Qatar [52].

In order to satisfy the energy demands for desalination facilities, the installation of new power generating facilities will be needed [41], which, in turn, will require copious amounts of cooling water 
see, e.g., [53,54]. Considering fossil fuel-based electricity generation, an increase by $40 \%$ of power generation in Middle Eastern countries has been estimated in order to secure water supply in 2050 [41].

A number of different desalination technologies have been developed over the last few decades. Of these, reverse osmosis technology (RO) is the most widely used [55], although GCC countries are globally unique in their heavy reliance on thermal desalination technologies [52]. The overall energy demand in RO plants has been estimated to amount to $3.7 \mathrm{kWhe} / \mathrm{m}^{3}$, i.e., for each $\mathrm{m}^{3}$ of potable water [56].

Looking specifically at the case of Cyprus, ever since desalination was introduced in 1996/97, its importance for the provision of drinking water has steadily increased (except for selected "wet years" such as 2012 and 2013). In 2015, the total volume of desalinated seawater amounted to about $37.5 \times 10^{6} \mathrm{~m}^{3}$ [38]. This required $0.14 \mathrm{GWh}$ of electricity for its production. In the same year, the Electricity Authority Cyprus, which supplies the bulk of electricity to the Cypriot consumers, generated 4128 GWh of electricity, consuming 947,226 tonnes of (largely fossil) fuel [57]. Thus, about $3.4 \%$ of electricity produced in Cyprus had to be used for desalination.

The considerations above underline the fact that the interrelationships between rising water and energy demands, in general, and of those in the MENA region/countries, in particular, require close attention by the decision makers in politics and the private and industrial sector. The aforementioned anticipated changes in climatic conditions further enhance demands and increase the risks to water and energy security in the region. Addressing these risks requires the provision of effective mitigation and adaptation strategies and measures. Some of the currently employed measures, and the clearly identifiable deficits in such measures, are briefly described in the following section.

\section{Adaptation/Mitigation Options and Strategies}

\subsection{General Considerations}

Maintaining energy and water security as well as adequate indoor living conditions in the MENA region undergoing progressive shifts in climate conditions, as outlined above, requires well-conceived measures. These measures should aim at minimizing the adverse effects of these changes (adaptation) and should address the reduction of forcings behind their origin (mitigation) effectively. Addressing the first issue, we need to find ways to enhance the adaptive capacity on the local, national, and regional scales to unavoidable changes in climatic conditions and their impacts. With regard to the second issue, it should be noted that while the total population of the MENA region accounts for only $5.8 \%$ of the global population, the emission of carbon dioxide from MENA countries stands at $8.6 \%$ [58]. Thus, mitigation measures are equally required in some of the MENA countries, specifically in Iran and Saudi Arabia. These countries rank seventh and eighth in the list of carbon-emitting countries worldwide [58].

In the framework of the Paris Agreement of the U.N. Framework Convention on Climate Change (UNFCCC), which was signed by 195 nations, Intended Nationally Determined Contributions (INDCs) related to greenhouse gas emission reductions have been agreed on [59]. The INDCs outline the climate actions that countries intend to take under the Paris Agreement, to become Nationally Determined Contributions (NDCs). As outlined by Griffiths [52], the MENA countries are divided in their responses with regard to specifying their NDCs [52]. While the GCC states have not made any unconditional commitments on greenhouse gas (GHG) emission reductions, all of the North African countries, with the exception of Egypt, have come up with at least some form of unconditional commitment (see Table 1 in [52]). Similarly, Israel, Jordan, Lebanon, Iraq, Iran, and Yemen have declared commitments to unconditional GHG emission reductions. It must therefore be concluded that only a few of the MENA countries are prepared to implement unconditional INDCs. This suggests that greenhouse gas abatement will not likely be a driving force for regional energy policy [52].

Given these sober facts regarding mitigation, the need to devise effective adaptation strategies remains an urgent priority, given the above outlined adverse impacts of climate change on the MENA 
region. This is particularly evident with regard to energy and water security in the region. However, the need to make progress in advancing equally effective mitigation strategies remains unchanged.

In the following, I will address some of the measures already applied or intended to be taken to address this need. While considering the region at large, I will provide a few specific examples from selected MENA countries below.

\subsection{Options/Measures/Strategies: Water}

There is a wide range of water adaptation options/strategies/measures that have been or can be taken. On a general level, this includes, but is not limited to:

- planning for extremes (floods): modeling and mapping flood extends and hazards;

- artificial recharge of groundwater resources by reservoirs and check dams;

- recharge of groundwater in severely depleted aquifers by tertiary-treated sewage water;

- (limited) use of tertiary treated sewage water in private households, public works, and agriculture;

- shifts from water intensive to draught tolerant crops to reduce irrigation water demands;

- supplemental irrigation of rain-fed winter crops instead of full irrigation of summer crops;

- rainwater harvesting for irrigation;

- more effective and more appropriately-timed irrigation measures;

- policies to reduce water demand, such as subsidies and extension support for modern irrigation systems;

- reforestation of marginal, abandoned agricultural lands;

- analysis of environmental flow requirements and options;

- improving rainfall-runoff management and stormwater use in urban areas, such as rain water harvesting for landscaping and groundwater recharge;

- improved leakage detection in urban water distribution systems;

- offering incentives for reduced water consumption in private households through tailored tariff systems.

This wide range of measures requires action and innovations in technology, agronomy and agriculture, civil and water engineering, and in public water administration on the local to national scale. While the implementation of a number of these measures are well underway in some of the MENA countries, a more integrative and holistic assessment of activities is needed to advance adaptation (and mitigation) in the water sector, which is still largely forthcoming.

With regard to concrete measures taken, Hoff et al. [60] provided some instructive examples of successful projects undertaken in MENA countries. While drip irrigation is a technology that has been pioneered and perfected in Israel over the last few decades [61-63], Hoff et al. [60] present an example of employing drip irrigation in a number of locations in Morocco. The example clearly underlines how such irrigation technology contributes to increasing water and energy efficiencies in agriculture. By using less water and requiring less energy for pumping, drip irrigation results in productivities that are similar to more conventional, much more water-intensive practices. By employing enhanced irrigation technology, water and energy efficiencies can actually improve agricultural productivity, gross margins, and food security [60].

Another example of successfully addressing the water-energy nexus in agriculture also stems from Morocco. Hoff et al. [60] showed how solar powered irrigation at the farm level in Marrakesh, Midelt, and the Moroccan Tata Province can significantly contribute to reducing the high energy demand and associated cost that is currently linked to modern irrigation technology. This not only reduces the costs of agricultural production, but also reduces the national import dependency for fossil fuel. However, care has to be taken to avoid overexploitation of groundwater resources by being misled by cost-free pumping and assuming that water is readily available. This notwithstanding, the practiced solar pumping provides an energy- and climate-smart agricultural water supply and thereby supports the shift of the energy system to renewables [60]. 
A variety of new and innovative technologies aimed to reduce water (and energy) consumption in urban settings have been presented by Pahl-Weber et al. [64].

\subsection{Options/Measures/Strategies: Energy}

Maintaining energy security in the region is particularly relevant with regard to the aforementioned growing electricity needs for space cooling, on the one hand, and for the generation of potable water through energy-intensive desalination, on the other. This will require additional energy production facilities, ideally without adding to the emission of greenhouse gases. As also explained above, these considerations should be taken into account by decision makers in MENA countries when considering the installation of additional power generation technologies [41].

In light of the earlier-mentioned shortcomings in sufficient and adequate mitigation measures in parts of the MENA region, the deployment of renewable energies in combination with enhanced energy efficiency provides significant opportunities to reduce greenhouse gas emissions. Shifting to renewables in the energy sector not only reduces greenhouse gas emissions, but also increases energy security in the MENA region by reducing import-dependencies of fossil fuels in some of the MENA countries. Moreover, and as mentioned before, renewable energy generation requires significantly less water for cooling compared to fossil-fuel based power plants, thus reducing water demand in the energy sector.

Given these considerations, it should be noted that the MENA region comprises a rich endowment of renewable energy resources, particularly solar and wind resources see, e.g., [65-67]. One of the drawbacks of wind and photovoltaic power systems (PV) is the fact that these technologies deliver only intermittent power and require considerable conventional backup. Griffiths (see Table 2 in [52]), based on [68] provides a compilation of various renewable energy potentials for MENA countries. With regard to solar power, the direct normal radiation (DNR), which characterizes the suitability for concentrated solar applications (see below), ranges between 2050 and $2800 \mathrm{k} \mathrm{Whm}^{-2} \mathrm{a}^{-1}$ in the MENA region, where cloud cover is rare [52]. However, the current renewable energy deployment in most of the states of the Middle East has been inadequate and well below this potential. With regard to the MENA region, as a whole, there are a few utility-scale projects in North Africa, Cyprus, and the United Arab Emirates (UAE). Renewable energy technologies have been primarily deployed for research, development, and demonstration purposes only [67].

Because of the already mentioned high solar direct radiation in most of the MENA countries [52,67], the employment of solar energy installations, in general, and that of concentrating solar energy plants (CSP plants), in particular, is seen as a viable alternative to conventional power plants [69] (Figure 8). As concluded by a study of the International Energy Agency (IEA), CSP plants alone could generate several times more electricity in the MENA region than the electricity consumption of the Arab region and Europe combined [70].

CSP plants have been in operation for commercial electricity generation for some time now (for basic reviews of CSP technology, see, e.g., [71-75]). The major elements of a CSP plant comprise:

- a field of fixed or movable mirrors (so-called "heliostats") that reflect infalling solar radiation onto a small receiver element;

- a transport fluid that is being heated to temperatures of several 100 degrees at the receiver;

- a storage medium (e.g., molten salt, concrete, phase-change material) that is being heated by the transport fluid and either maintains the energy for future use or provides heat directly to conventional electricity generating devices, such as steam or gas turbines or a Stirling engine.

A major advantage of CSP plants lies in the use of a thermal energy storage device/tank. In addition, CSP plants can also readily utilize alternative fuels in hybrid operation. Extracting thermal energy from the storage for electricity production once the sun has set can overcome the intermittency problems of many of the other renewable energy technologies [69] and enables the provision of stable and constant power regardless of the time of the day. Ultimately, a $24 \mathrm{~h} / 365$ day operation of a CSP 
plant may become feasible (for more details, see: [55]). As a consequence, CSP plants can save more fossil fuel and replace more conventional power capacity compared to other renewable energy sources, such as PV and wind power (for more details, see: [55]). It is therefore not surprising that the CSP technology is seen as one of the major renewable energy technologies in the MENA region in general, and in the GCC countries in particular $[66,68]$.

However, the CSP technology has also the potential to accomplish the production of both electricity and water in a single facility. In the next section, I will provide the example of an experimental CSP plant where this potential has been exploited. While plans for such facilities have been around for some time and on much larger scales [69,76-79], the experimental facility of the Cyprus Institute has made significant progress in realizing such a plant [80].

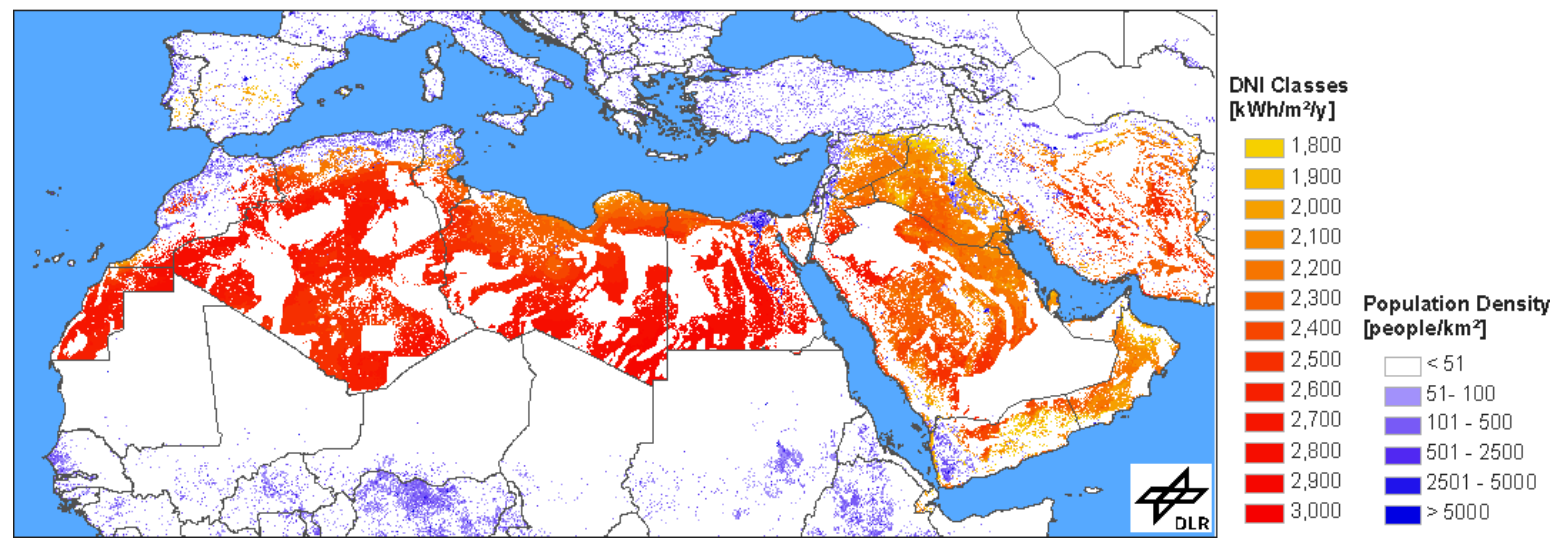

Figure 8. Concentrating solar power potential in the MENA region; source: ESTELLA (http://www.estelasolar.org/ste-soon-a-major-power-source-in-sunbelt-countries/how-ste-can-bringbenefits-to-mena-region/).

\subsection{A CSP Plant for the Co-Generation of Electricity and Desalinated Seawater}

As outlined above, a new development has advanced the employment of CSP technology for the co-production of electricity and desalinated seawater (DSW) see, e.g., [55,69,78,81]. As mentioned above, plants of this type (called CSP-DSW plants), have the advantage of addressing two particularly relevant challenges in the context of the WEN in arid to sub-arid regions, i.e., the generation of "green" electricity and the provision of drinking water through renewable power sources. The plant of the Cyprus Institute, the PROTEAS CSP field facility, employs heliostats [82,83] instead of fixed parabolic mirrors, as is conventionally practiced $[69,78]$. This enables the operation of CSP-DSW plants in hilly, coastal terrain, which is the more typical setting in smaller island states such as Cyprus.

Given these advantages, there are, however, a number of challenges to be mastered. This includes the integration of all components in a coherent, well-functioning plant and the substantial capital investments needed for the realization of such a facility. Over the last few years, research at the Cyprus Institute's Energy, Environment, and Water Research Center (EEWRC) has seen tremendous progress in overcoming these challenges $[76,84]$. The experimental facility at Pentakomo, at the southern coast of Cyprus, incorporates the following (Figure 9):

- energy harvesting through several tens of Heliostats on a hilly, south facing location $[83,85]$;

- the employment of a central receiver, designed and built at EEWRC;

- a newly designed molten-salt thermal storage tank [86];

- a steam extraction turbine for electricity production; and

- an innovative multiple effect distillation facility (MED) with a thermal vapor compressor for the desalination of seawater $[87,88]$.

While the plant is about to become operational, plans are underway for a larger, prototype-plant in the foreseeable future [88]. 


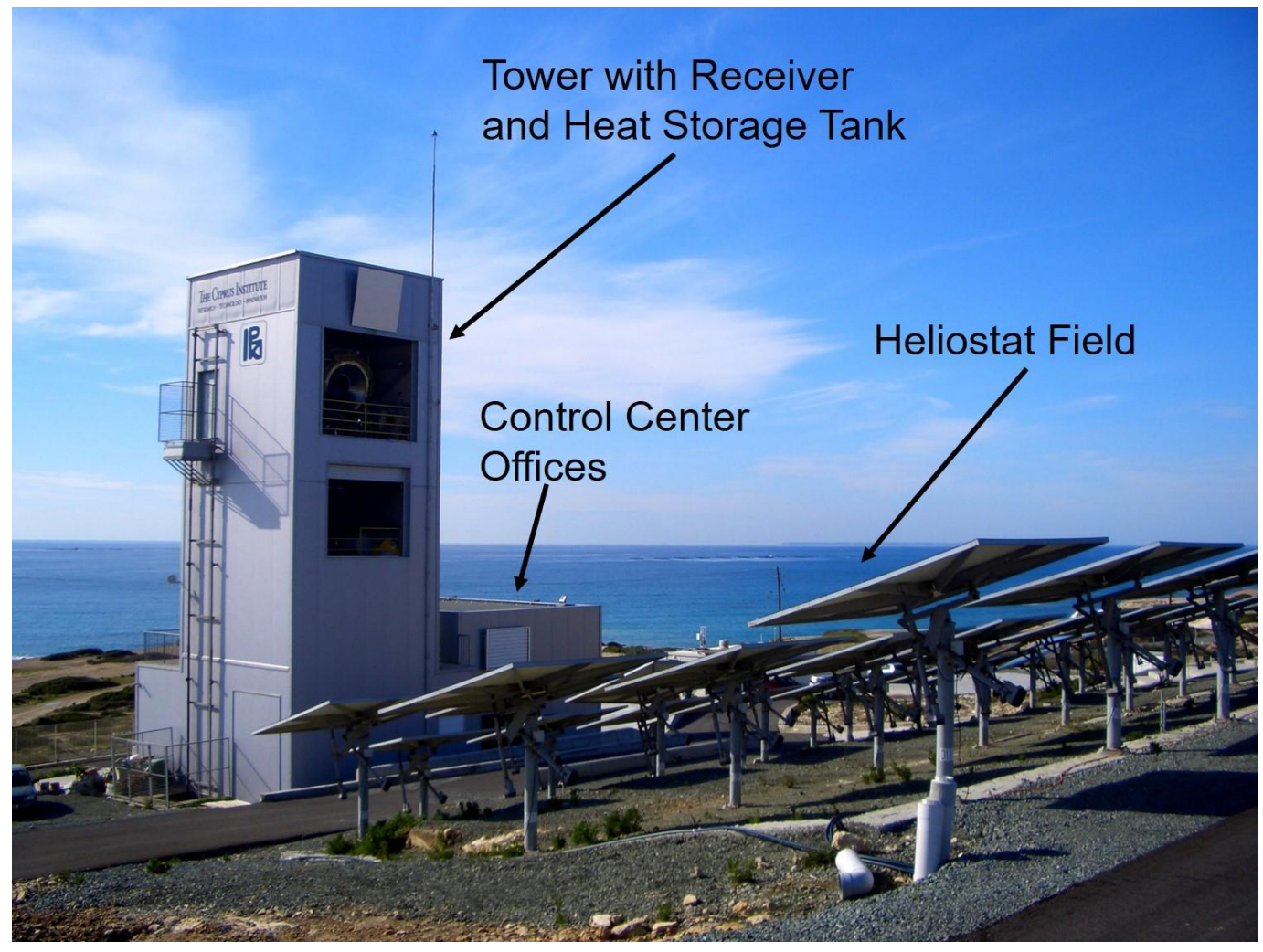

Figure 9. The PROTEAS CSP field facility of the Cyprus Institute (see above; photograph: M. Lange).

\section{Conclusions}

In returning to the main questions posed in the introductory section of this paper, it is noted that the MENA region (Middle East and North Africa) and the Eastern Mediterranean represent a region with distinct characteristics that is different from many parts of the world. The region is home to one of the fastest growing populations on the globe, having experienced a roughly four-fold population increase, from about 110 million in 1950 to 569 million in 2017 [17]. This has been accompanied by a significantly increasing urbanization trend [19], which is expected to continue until the end of this century [20].

The MENA region is known for its stark environmental gradients as well as for large differences in the provision of ecosystem services and available water, both from East to West and from South to North. The prevailing scarcity of available water resources and the prospects of continued decreases in precipitation have significant ramifications for water and food security in the region. Despite some commonalities, MENA countries are characterized by significant differences in their political, economic, societal, ideological, and religious settings. Because of the varying degrees of natural resource availabilities, some of the countries (particularly those on the Arabic Peninsula), provide sufficient economic prospects to their citizens, while in others, a large fraction of the population has to endure significant economic hardship. This is also reflected in the differences regarding the availability and pricing of water and energy to MENA communities that may be larger than in other regions of the world.

Adding to these challenges are the events of the Arab Spring, which have resulted in major political, economic, and societal transitions since 2010. These transitions and the ongoing armed struggles within and between countries of the MENA region have resulted in the dismantling of major infrastructure installations needed for a secure provision of basic commodities, such as water and energy (for more background, please see: [14-16]). This might also be seen as distinguishing the MENA region from other parts of the world. 
Turning to our second question, numerous climate modeling studies clearly indicate that more severe climatic changes are expected in the Mediterranean Basin and the MENA region compared to other parts of the globe see, e.g., [13]. Results of regional climate modeling have demonstrated that countries in the region will face significant increases in summer temperatures and increasing numbers of heat waves, accompanied by long drought periods and a non-uniform, but locally significant, decrease in precipitation $[11,27]$.

The impacts of climatic changes will be exacerbated in the large cities of the MENA region. As a result of the "urban heat island effect", the temperature in the inner cities will be $2-3{ }^{\circ} \mathrm{C}$ higher than the surrounding rural areas e.g., [35-37]. Moreover, projections of future summer temperatures in capitals of the MENA countries will lie significantly above current temperatures [29]. In combination with poor air quality, this will have profound adverse consequences for the health of urban communities [11].

How can these impacts of climate change be understood in the context of the water-energy nexus (WEN) [1,2,32,40-45]? The WEN concept enables more comprehensive and more holistic considerations and analysis regarding the scarcity and resource security of water and energy, which are often interrelated and mutually dependent.

The need for rising energy and electricity demands requires the construction of additional electricity generation capacities. However, this does not only necessitate significant capital investments by state authorities and the private sector in the coming years, it also requires the application of holistic assessment approaches for decisions about the electricity generation technologies to be employed. Selecting renewable energy technologies instead of conventional, hydrocarbon driven technologies enables the utilization of a rich endowment of renewable energy resources in the MENA region, particularly solar and wind resources see, e.g., [65-67]. Renewable technologies also have a clear advantage over conventional technologies by reducing greenhouse gas emissions and by being less water demanding [41].

In order to satisfy the increasing demand for potable water, the energy-intensive desalination of seawater has been employed already and is going to play a key role in the water supply system of MENA countries in the foreseeable future. However, seawater desalination represents a highly energy-intensive technology, which will require the installation of new power generating facilities [42]. This, in turn, will entail rising greenhouse gas emissions and the provision of copious amounts of cooling water [54,55].

It is apparent that the anticipated changes in climatic conditions and their impacts will enhance demands of basic commodities and will increase the risks to water and energy security in the region. An approach based on the Water-Energy-Nexus concept (WEN approach) helps to understand these risks and possible mitigation and adaptation strategies and measures holistically and more comprehensively.

This brings me to the fourth main question that this paper aims to answer. With regard to enhancing water and energy security in countries of the region, measures should aim at minimizing the adverse effects of these changes (adaptation) and should address the possible reduction of forcings behind their origin (mitigation) effectively. As far as mitigation is concerned, there are significant shortcomings in many of the MENA countries and greenhouse gas abatement will not likely be a driving force for regional energy policy [52]. Given the above outlined adverse impacts of climate change on the MENA region, the need to devise effective adaptation strategies has to be seen as an urgent priority. This is particularly evident with regard to energy and water security in the region.

While a number of well-established adaptation measures are well underway in some of the MENA countries, a more integrative and holistic advancement of adaptation (and mitigation) in the water sector is still largely forthcoming. However, Hoff et al. [60] provided some examples of successful agricultural techniques that enhance water and energy efficiencies in climate-smart agriculture and improve productivity, gross margins, and food security [60]. Pahl-Weber et al. [64] present a variety of new and innovative technologies aimed to reduce water (and energy) consumption in the urban built environment. 
Employing renewable energies in combination with implementing enhanced energy efficiencies provides significant opportunities for mitigation and adaptation. The use of renewables in the energy sector not only reduces greenhouse gas emissions and decreases the amount of coolant water in power plants, but also increases energy security in the MENA region by contributing to lessening import dependencies of countries without hydrocarbon deposits.

However, despite the rich endowment of renewable energy resources, particularly solar and wind resources [66-68], the current deployment of renewables has been inadequate and well below the available potential in most of the states of the MENA countries. In addition, the intermittency of wind and photovoltaic power systems (PV), which require considerable conventional backup, has limited the acceptance of these two most prominent technologies in many of the MENA countries.

The employment of a relatively new and innovative technology, focusing on the utilization of concentrated solar power (CSP), is seen as a more promising alternative to the aforementioned PV and wind technologies and to conventional power plants [70]. A major advantage of CSP plants lies in the employment of a thermal energy storage device/tank. Thermal energy storage enables the provision of stable and constant power, regardless of the time of the day or the availability or absence of wind. Consequently, CSP plants can save more fossil fuel and replace more conventional power capacity compared to other renewable energy sources, such as PV and wind power (for more details, see [56]).

However, the CSP technology has also the potential to do even more. By employing CSP to co-produce electricity and desalinated seawater in an integrated facility (DSW) $[56,70,79,82]$, two particularly relevant challenges in the context of the WEN in arid to sub-arid regions are addressed, i.e., the generation of "green" electricity and the provision of drinking water through renewable power sources. Significant progress in realizing such a plant has been made by the Cyprus Institute's PROTEAS CSP field facility [81]. While still mainly considered a field experiment, the knowledge and experiences gained with this facility will pave the way to advancing the CSP-DSW technology.

Thus, while a number of promising adaptation/mitigation options/strategies exist, their implementation is often hindered by the prevalence of sectoral/silo thinking, and thus are still forthcoming in many of the MENA countries. Moreover, the aforementioned differences in major political and societal characteristics of MENA countries have so far prevented a more common and united approach that transcends national borders. It is therefore concluded that a multi-level, multi-sectoral, and multi-scale strategy, that includes all relevant stakeholders and an attempt at policy making across political borders, will be needed to address the challenges of the WEN to the region.

On a more general level, the challenges to energy and water security and their links to ongoing and future climate change, if not dealt with adequately and in a timely fashion, will risk the reinforcement of existing social inequalities. This, in turn, may trigger additional political instability and possible conflicts in individual countries, as well as in the MENA region as a whole. In addition, a continued reliance on energy and food subsidies aimed at legitimizing existing political regimes, as seen in some of the MENA countries, proliferates an inefficient use and distribution of energy and water [89].

As outlined above, the fundamental links between energy, water, climate, development, and political stability in the MENA region require policy-makers to address these interdependent challenges urgently and in cooperation between the individual countries. This will enable economic growth without neglecting its distributive and environmental aspects. It is concluded that an integrated approach, as briefly outlined above, can be achieved through creating regional cooperation and a joint research and stakeholder community. This will contribute to the secure and sustainable future well-being of MENA societies.

Funding: This research received no external funding.

Acknowledgments: I would like to acknowledge numerous constructive suggestions and criticisms by a number of reviewers that have improved the quality of this paper.

Conflicts of Interest: The author declares no conflict of interest. 


\section{References}

1. Schnoor, J.L. Water-energy nexus. Environ. Sci. Technol. 2011, 45, 5065. [CrossRef] [PubMed]

2. Siddiqi, A.; Anadon, L.D. The water-energy nexus in Middle East and North Africa. Energy Policy 2011, 39 , 4529-4540. [CrossRef]

3. Hoff, H. Understanding the Nexus. Background Paper for the Bonn 2011 Conference: The Water, Energy and Food Security Nexus; Stockholm Environment Institute: Stockholm, Sweden, 2011; p. 52. Available online: http://www.water-energy-food.org/documents/understanding_the_nexus.pdf (accessed on 12 October 2018).

4. Simelane, T.; Mohee, R. Future Directions of Solid Waste Management in Africa; Africa Institute of South Africa: Pretoria, South Africa, 2015; p. 250.

5. ACP-EC Joint Parliamentary Assembly. Urbanisation Challenges, Waste Management, and Development; UN-HABITAT: Nairobi, Kenya, 2014; p. 3.

6. Panayotou, T. Globalization and Environment; Center for International Development at Harvard University: Cambridge, MA, USA, 2000; p. 50. Available online: https://ideas.repec.org/p/cid/wpfacu/53a.html (accessed on 22 November 2018).

7. Nadjam, A.; Runnels, D.; Halle, M. Environment and Globalization: Five Propositions (2010). In The Globalizationa and Environment Reader; Newell, P., Roberts, J.T., Eds.; Wiley Blackwell: Oxford, UK, 2017; pp. 94-108.

8. Yusuf, S.; Evenett, S.; Wu, W. Facets of Globalization: International and Local Dimensions of Developmen; The World Bank: Washington, DC, USA, 2001; p. 500.

9. EEA. Adaptation in Europe-Addressing Risks and Opportunities from Climate Change in the Context of Socio-economic Developments. 2013; p. 132. Available online: https://www.osti.gov/etdeweb/servlets/purl/ 22094229 (accessed on 22 July 2018).

10. Kostopoulou, E.; Giannakopoulos, C.; Hatzaki, M.; Karali, A.; Hadjinicolaou, P.; Lelieveld, J.; Lange, M. Assessment of Climate Change Extremes Over the Eastern Mediterranean and Middle East Region Using the Hadley Centre PRECIS Regional Climate Model. In Advances in Meteorology, Climatology and Atmospheric Physics; Springer: Berlin/Heidelberg, Germany, 2013; pp. 547-554.

11. Lelieveld, J.; Hadjinicolaou, P.; Kostopoulou, E.; Chenoweth, J.; El Maayar, M.; Giannakopoulos, C.; Hannides, C.; Lange, M.; Tanarhte, M.; Tyrlis, E. Climate change and impacts in the Eastern Mediterranean and the Middle East. Clim. Chang. 2012, 114, 667-687. [CrossRef] [PubMed]

12. World Bank. Beyond Scarcity: Water Security in the Middle East and North Africa; License: Creative Commons Attribution CC BY 3.0 IGO; World Bank: Washington, DC, USA, 2017; p. 233.

13. Giorgi, F. Climate change Hot-Spots. Geophys. Res. Lett. 2006, 33, L08707. [CrossRef]

14. FAO. Water Management in Fragile Systems Building Resilience to Shocks and Protracted Crises in The Middle East and North Africa; Food and Agriculture Organization of the United Nations: Cairo, Egypt, 2018; p. 74. Available online: http://www.fao.org/emergencies/resources/documents/resources-detail/en/c/1151116/ (accessed on 25 October 2018).

15. World Bank. The Toll of War-the Economic and Social Consequences of the Conflict in Syria. 2017, p. 148. Available online: https://www.worldbank.org/en/country/syria/publication/the-toll-of-war-the-economicand-social-consequences-of-the-conflict-in-syria (accessed on 4 December 2019).

16. Jobbins, G.; Commins, S.; Welham, B. Water Security in the Protracted Crises and Post-conflict Reconstruction of the Middle East; Overseas Development Institute: London, UK, 2018; p. 6. Available online: https: //www.odi.org/sites/odi.org.uk/files/resource-documents/12157.pdf (accessed on 3 September 2019).

17. UNDESA. World Population Prospects: The 2017 Revision. Available online: https://esa.un.org/unpd/wpp (accessed on 5 September 2018).

18. McKee, M.; Keulertz, M.; Habibi, N.; Mulligan, M.; Woertz, E. Demographic and Economic Material Factors in the MENA region. 2017, p. 43. Available online: http://www.iai.it/sites/default/files/menara_wp_3.pdf (accessed on 3 December 2019).

19. UNEP/MAP. State of the Mediterranean Marine and Coastal Environment; UNEP/MAP-Barcelona Convention: Athens, Greece, 2012.

20. United Nations. The State of Arab Cities 2012: Challenges of Urban Transition; UN-Habitat, United Nations Human Settlements Programme: Nairobi, Kenya, 2012. 
21. Stocker, T. Climate Change 2013: The Physical Science Basis: Working Group I Contribution to the Fifth Assessment Report of the Intergovernmental Panel on Climate Change; Cambridge University Press: Cambridge, UK, 2014.

22. Pal, J.S.; Eltahir, E.A.B. Future temperature in southwest Asia projected to exceed a threshold for human adaptability. Nat. Clim. Chang. 2015, 6, 197. [CrossRef]

23. Christensen, J.H.; Hewitson, B.; Busuioc, A.; Chen, A.; Gao, X.; Held, R.; Jones, R.; Kolli, R.K.; Kwon, W.K.; Laprise, R.; et al. Regional climate projections. In Climate Change, 2007: The Physical Science Basis. Contribution of Working Group I to the Fourth Assessment Report of the Intergovernmental Panel on Climate Change; Solomon, S., Qin, D., Manning, M., Marquis, M., Averyt, K., Tignor, M.M.B., LeRoy Miller, H.J., Chen, Z., Eds.; Cambridge University Press: Cambridge, UK, 2007; Chapter 11; pp. 847-940.

24. Hadjinicolaou, P.; Giannakopoulos, C.; Zerefos, C.; Lange, M.A.; Pashiardis, S.; Lelieveld, J. Mid-21st century climate and weather extremes in Cyprus as projected by six regional climate models. Reg. Environ. Chang. 2010, 11, 441-457. [CrossRef]

25. Bucchignani, E.; Mercogliano, P.; Panitz, H.-J.; Montesarchio, M. Climate change projections for the Middle East-North Africa domain with COSMO-CLM at different spatial resolutions. Adv. Clim. Chang. Res. 2018, 9, 66-80. [CrossRef]

26. Jones, R.G.; Noguer, M.; Hassell, D.C.; Hudson, D.; Wilson, S.S.; Jenkins, G.J.; Mitchell, J.F.B. Generating High Resolution Climate Change Scenarios Using PRECIS; Met Office Hadley Centre: Exeter, UK, 2004; p. 40. Available online: https://unfccc.int/files/national_reports/non-annex_i_natcom/cge/application/pdf/precis_ flyers_cop9_rcm.pdf (accessed on 14 September 2018).

27. Lelieveld, J.; Proestos, Y.; Hadjinicolaou, P.; Tanarhte, M.; Tyrlis, E.; Zittis, G. Strongly increasing heat extremes in the Middle East and North Africa (MENA) in the 21st century. Clim. Chang. 2016, 137, 245-260. [CrossRef]

28. Zittis, G.; Hadjinicolaou, P.; Lelieveld, J. Role of soil moisture in the amplification of climate warming in the Eastern Mediterranean and the Middle East. Clim. Res. 2014, 59, 27-37. [CrossRef]

29. Lelieveld, J.; Hadjinicolaou, P.; Kostopoulou, E.; Giannakopoulos, C.; Pozzer, A.; Tanarhte, M.; Tyrlis, E. Model projected heat extremes and air pollution in the eastern Mediterranean and Middle East in the twenty-first century. Reg. Environ. Chang. 2014, 14, 1937-1949. [CrossRef]

30. Kostopoulou, E.; Giannakopoulos, C.; Hatzaki, M.; Karali, A.; Hadjinicolaou, P.; Lelieveld, J.; Lange, M.A. Spatio-temporal patterns of recent and future climate extremes in the eastern Mediterranean and Middle East region. Nat. Hazards Earth Syst. Sci. 2014, 14, 1565-1577. [CrossRef]

31. Döll, P.; Flörke, M. Global-Scale Estimation of Diffuse Groundwater Recharge; Institute of Physical Geography, Frankfurt University: Frankfurt am Main, Germany, 2005; Available online: https://www.uni-frankfurt.de/ 45217767/FHP_03_Doell_Floerke_2005.pdf (accessed on 17 October 2017).

32. Mohtar, R. Climate Change and the Water-Energy-Food Nexus in the MENA Region. 2017. Available online: https://econpapers.repec.org/paper/ocpppaper/pb-1739.htm (accessed on 1 June 2019).

33. Chenoweth, J.; Hadjinicolaou, P.; Bruggeman, A.; Lelieveld, J.; Levin, Z.; Lange, M.A.; Xoplaki, E.; Hadjikakou, M. Impact of climate change on the water resources of the eastern Mediterranean and Middle East region: Modeled 21st century changes and implications. Water Resour. Res. 2011, 47. [CrossRef]

34. United Nations Department of Economic and Social Affairs Population Division. World Urbanization Prospects: The 2014 Revision, Highlights. 2014. Available online: https://www.compassion.com/multimedia/ world-urbanization-prospects.pdf (accessed on 9 December 2018).

35. Yang, L.; Qian, F.; Song, D.-X.; Zheng, K.-J. Research on Urban Heat-Island Effect. Procedia Eng. 2016, 169, 11-18. [CrossRef]

36. Arnfield, A.J. Two decades of urban climate research: A review of turbulence, exchanges of energy and water, and the urban heat island. Int. J. Climatol. 2003, 23, 1-26. [CrossRef]

37. Santamouris, M. Heat Island Research in Europe-The State of the Art. J. Adv. Build. Energy Res. (Rev. Pap.) 2007, 1, 123-150. [CrossRef]

38. Neocleous, N. Cyprus Water Security Experience; Water Development Department, Ministry of Agriculture, Rural Development and Environment, Republic of Cyprus. 2017; p. 74 . Available online: http://www.moa.gov.cy/moa/wdd/wdd.nsf/All/3BF7D7F6B7875951C2258287003A56C0/\$file/Cyprus_ Water_Security_Experience.pdf?OpenElement (accessed on 19 September 2018). 
39. Transmission System Operator Cyprus. Historical Monthly Minimum and Maximum Energy Demandand-1994-Sep06. Available online: https://view.officeapps.live.com/op/view.aspx?src=https: //www.dsm.org.cy/media//attachments/Load\%20Data/HistoricalMonthlyMinMaxDemandandEnergy1994-Sep06.xls (accessed on 19 September 2018).

40. Desai, S.; Klanecky, D.A. Meeting the Needs of the Water-energy nexus. Chem. Eng. Prog. 2011, 107, $22-27$.

41. Fink, T. The Water-Energy-Climate Nexus-linkages and trade-offs in the Middle East and North Africa (MENA) region. 2018. Available online: https://research.sharqforum.org/2018/08/14/the-water-energyclimate-nexus-linkages-and-trade-offs-in-the-middle-east-and-north-africa-mena-region/ (accessed on 3 November 2018).

42. Al-Saidi, M.; Birnbaum, D.; Buriti, R.; Diek, E.; Hasselbring, C.; Jimenez, A.; Woinowski, D. Water Resources Vulnerability Assessment of MENA Countries Considering Energy and Virtual Water Interactions. Procedia Eng. 2016, 145, 900-907. [CrossRef]

43. Hamiche, A.M.; Stambouli, A.B.; Flazi, S. A review of the water-energy nexus. Renew. Sustain. Energy Rev. 2016, 65, 319-331. [CrossRef]

44. Menegaki, A.N.; Ozturk, I. Renewable energy, rents and GDP growth in MENA countries. Energy Sour. Part B Econ. Plan. Policy 2016, 11, 824-829. [CrossRef]

45. Menegaki, A.N.; Tiwari, A.K. A global food-energy-water nexus with heterogeneity, non-stationarity and cross-sectional dependence. Qual. Quant. 2018, 52, 2723-2755. [CrossRef]

46. Asimakopoulos, D.A.; Santamouris, M.; Farrou, I.; Laskari, M.; Saliari, M.; Zanis, G.; Giannakidis, G.; Tigas, K.; Kapsomenakis, J.; Douvis, C.; et al. Modelling the energy demand projection of the building sector in Greece in the 21st century. Energy Build. 2012, 80, 488-498. [CrossRef]

47. Giannakopoulos, C.; Hadjinicolaou, P.; Zerefos, C.; Demosthenous, G. Changing energy requirements in the mediterranean under changing climatic conditions. Energies 2009, 2, 805-815. [CrossRef]

48. Giannakopoulos, C.; Kostopoulou, E.; Hadjinicolaou, P.; Hatzaki, M.; Karali, A.; Lelieveld, J.; Lange, M.A. Impacts of Climate Change Over the Eastern Mediterranean and Middle East Region Using the Hadley Centre PRECIS RCM. In Advances in Meteorology, Climatology and Atmospheric Physics; Springer: Berlin/Heidelberg, Germany, 2013; pp. 457-463. [CrossRef]

49. International Energy Agency. World Energy Outlook 2016; International Energy Agency (IEA): Paris, France, 2016. [CrossRef]

50. World Bank. Renewable Energy Desalination: An. Emerging Solution to Close the Water Gap in the Middle East. and North. Africa; World Bank, Water Partnership Program (WPP): Washington, DC, USA, 2012. [CrossRef]

51. NAS. Desalination: A National Perspective; National Research Council of the National Academies: Washington, DC, USA, 2008; p. 254. Available online: http://www.nap.edu/catalog/12184.html (accessed on 17 January 2017).

52. Griffiths, S. A review and assessment of energy policy in the Middle East and North Africa region. Energy Policy 2017, 102, 249-269. [CrossRef]

53. Kohli, A.; Frenken, K. Cooling Water for Energy Generation and its Impact on National-level Water Statistics; 2011; p. 5. Available online: https://www.researchgate.net/publication/265117624_Cooling_water_for_energy_ generation_and_its_impact_on_national-level_water_statistics (accessed on 24 October 2018).

54. Torcellini, P.; Long, N.; Judkoff, R. Consumptive Water Use for U.S. Power Production. 2003. Available online: https://www.nrel.gov/docs/fy04osti/33905.pdf (accessed on 11 November 2018).

55. Lange, M.A. Renewable Energy and Water Resources. In Climate Vulnerability; Volume 3: Vulnerability of Energy to Climate; Pielke, S.R., Kallos, G., Eds.; Elsevier Inc.: San Diego, CA, USA, 2013; pp. 149-166.

56. Semiat, R. Energy Issues in Desalination Processes. Environ. Sci. Technol. 2008, 42, 8193-8201. [CrossRef] [PubMed]

57. Electricity Authority Cyprus. Annual Report 2015. 2016, p. 106. Available online: https://www.eac.com.cy/ EN/EAC/FinancialInformation/Documents/Annual\%20Report-English\%202015-FINAL.pdf (accessed on 16 October 2018).

58. CARBOUN. Climate Change in the Middle East and North Africa: Carbon Emissions. Available online: http://www.carboun.com/infographics/climate-change-in-the-middle-east-and-north-africa-carbonemissions/ (accessed on 21 September 2018). 
59. Dagnet, Y.; Waskow, D.; Elliot, C.; Northrop, E.; Thwaites, J.; Mogelgaard, K.; Krnjaic, M.; Levin, K.; McGray, H. Staying on Track from Paris: Advancing the Key Issues of the Paris Agreement; World Resources Institute: Washington, DC, USA, 2016; Available online: http//www.wri.org/ontrackfromparis (accessed on 17 May 2019).

60. Hoff, H.; Alrahaife, S.A.; El Hajj, R.; Lohr, K.; Mengoub, F.E.; Farajalla, N.; Fritzsche, K.; Jobbins, G.; Özerol, G.; Schultz, R.; et al. A Nexus Approach for the MENA region-From Concept to Knowledge to Action. Front. Environ. Sci. 2019, 7. [CrossRef]

61. Fishelson, G.; Rymon, D. Adoption of agricultural innovations: The case of drip irrigation of cotton in Israel. Technol. Forecast. Soc. Chang. 1989, 35, 375-382. [CrossRef]

62. Oron, G.; DeMalach, Y.; Gillerman, L.; David, I.; Rao, V.P. Improved saline-water use under subsurface drip irrigation. Agric. Water Manag. 1999, 39, 19-33. [CrossRef]

63. Dasberg, S.; Or, D. Practical Applications of Drip Irrigation. In Drip Irrigation; Dasberg, S., Or, D., Eds.; Springer: Berlin/Heidelberg, Germany, 1999; pp. 125-138.

64. Pahl-Weber, E.; Seelig, S.; Ohlenburg, H.; Bergmann, N.K.V. Urban. Challenges and Urban. Design Approaches for Resource-Efficient and Climate-Sensitive Urban. Design in the MENA Region; Pahl-Weber, E., Seelig, S., Ohlenburg, H., Bergmann, N.K.V., Eds.; Berlin Universitätsverlag der TU Berlin: Berlin, Germany, 2013; p. 212.

65. Nematollahi, O.; Hoghooghi, H.; Rasti, M.; Sedaghat, A. Energy demands and renewable energy resources in the Middle East. Renew. Sustain. Energy Rev. 2016, 54, 1172-1181. [CrossRef]

66. IRENA. Renewable Energy Market. Analysis: The GCC Region; International Renewable Energy Agency (IRENA): Abu Dhabi, UAE, 2016; p. 96. Available online: https://www.irena.org/-/media/Files/IRENA/ Agency/Publication/2016/IRENA_Market_GCC_2016.pdf (accessed on 10 May 2019).

67. IRENA. Pan-Arab Renewable Energy Strategy 2030: Roadmap of Actions for Implementation; The International Renewable Energy Agency (IRENA) and the League of Arab States: Abu Dhabi, UAE, 2014; p. 108. Available online: https:/www.irena.org/publications/2014/Jun/Pan-Arab-Renewable-Energy-Strategy-2030-Roadmapof-Actions-for-Implementation (accessed on 10 May 2019).

68. Jacobson, M.Z.; Delucchi, M.A.; Bauer, Z.A.F.; Goodman, S.C.; Chapman, W.E.; Cameron, M.A.; Bozonnat, C.; Chobadi, L.; Clonts, H.A.; Enevoldsen, P.; et al. 100\% Clean and Renewable Wind, Water, and Sunlight All-Sector Energy Roadmaps for 139 Countries of the World. Joule 2017, 1, 108-121. [CrossRef]

69. Trieb, F.; Moser, M.; Scharfe, J.; Tomasek, M.L.; Kern, J.; Nieseor, T.; Cottret, N.; Glueckstern, P.; David, I.; Priel, M. Combined Solar Power and Desalination Plants: Techno-Economic Potential in Mediterranean Partner Countries-WP1: Technology Review and Selection of CSP and Desalination Configurations Adapted for Application in the Southern and Eastern Mediterranean Region; Final Report; MED-CSD: Stuttgart, Germany, 2009; p. 117.

70. IEA. World Energy Outlook 2010; The Organisation for Economic Co-operation and Development (OECD)/International Energy Agency (IEA): Paris, France, 2010; p. 738. Available online: https: //www.iea.org/publications/freepublications/publication/weo2010.pdf (accessed on 10 May 2019).

71. Fuqiang, W.; Ziming, C.; Jianyu, T.; Yuan, Y.; Yong, S.; Linhua, L. Progress in concentrated solar power technology with parabolic trough collector system: A comprehensive review. Renew. Sustain. Energy Rev. 2017, 79, 1314-1328. [CrossRef]

72. Ho, C.K.; Iverson, B.D. Review of high-temperature central receiver designs for concentrating solar power. Renew. Sustain. Energy Rev. 2014, 29, 835-846. [CrossRef]

73. Pelay, U.; Luo, L.; Fan, Y.; Stitou, D.; Rood, M. Thermal energy storage systems for concentrated solar power plants. Renew. Sustain. Energy Rev. 2017, 79, 82-100. [CrossRef]

74. Zhang, H.L.; Baeyens, J.; Degrève, J.; Cacères, G. Concentrated solar power plants: Review and design methodology. Renew. Sustain. Energy Rev. 2013, 22, 466-481. [CrossRef]

75. Weinstein, L.A.; Loomis, J.; Bhatia, B.; Bierman, D.M.; Wang, E.N.; Chen, G. Concentrating Solar Power. Chem. Rev. 2015, 115, 12797-12838. [CrossRef] [PubMed]

76. Fylaktos, N.; Mitra, I.; Tzamtzis, G.; Papanicolas, C.N. Economic analysis of an electricity and desalinated water cogeneration plant in Cyprus. Desalin. Water Treat. 2015, 55, 2453-2470. [CrossRef]

77. Lange, M.A. Renewable Energy and Water Resources. Clim. Vulnerability 2013, 3, 149-166. [CrossRef]

78. Trieb, F.; Müller-Steinhagen, H.; Kern, J.; Scharfe, J.; Kabariti, M.; Al Taher, A. Technologies for large scale seawater desalination using concentrated solar radiation. Desalination 2009, 235, 33-43. [CrossRef] 
79. Trieb, F.; Schillings, C.; Kronshage, S.; Viebahn, P.; May, N.; Paul, C.; Kabariti, M.; Bennouna, A.; Nokraschy, H.; Hassan, S.; et al. Trans.-Mediterranean Interconnection for Concentrating Solar Power (Trans.-CSP Study Report); German Aerospace Center (DLR), Institute of Technical Thermodynamics Section Systems Analysis and Technology Assessment. 2006, p. 190. Available online: http://www.dlr.de/tt/Portaldata/41/Resources/ dokumente/institut/system/projects/TRANS-CSP_Full_Report_Final.pdf (accessed on 25 December 2018).

80. Papanicolas, C.N. Research and Development Study for a Concentrated Solar Power-Desalinization of Sea Water (CSP-DSW) Project; The Cyprus Institute: Nicosia, Cyprus, 2010; p. 223.

81. Trieb, F.; Schillings, C.; Kronshage, S.; Viebahn, P.; May, N.; Paul, C.; Klann, U.; Kabariti, M.; Bennouna, A.; Nokraschy, H.; et al. Concentrating Solar Power for the Mediterranean Region. (MED-CSP Study Report); German Aerospace Center (DLR), Institute of Technical Thermodynamics Section Systems Analysis and Technology Assessment. 2005, p. 285. Available online: http://www.dlr.de/tt/Portaldata/41/Resources/dokumente/institut/ system/projects/MED-CSP_Full_report_final.pdf (accessed on 12 September 2018).

82. Bonanos, A.M.; Georgiou, M.C.; Guillen, E.; Papanicolas, C.N. CSP+D: The Case Study at the PROTEAS Facility. 2017. Available online: https://aip.scitation.org/doi/pdf/10.1063/1.4984564 (accessed on 8 August 2018).

83. Bonanos, A.M. Error analysis for concentrated solar collectors. J. Renew. Sustain. Energy 2012, 4, 063125. [CrossRef]

84. The Cyprus Institute. The CSP-DSW Project-An Overview. 2010. Available online: http://eewrc.cyi.ac.cy/ system/files/CSP-DSW\%20Stydy\%20Overview.pdf (accessed on 30 September 2018).

85. Georgiou, M.D.; Bonanos, A.M.; Georgiadis, J.G. Optical evaluation of heliostat mirrors using caustics. J. Renew. Sustain. Energy 2013, 5. [CrossRef]

86. Votyakov, E.; Bonanos, A.M. A perturbation model for stratified thermal energy storage tanks. Int. J. Heat Mass Transf. 2014, 75, 218-223. [CrossRef]

87. Georgiou, M.C.; Bonanos, A.M.; Georgiadis, J.G. Experimental evaluation of a multiple-effect distillation unit in low seawater flow conditions. Desalin. Water Treat. 2014, 52. [CrossRef]

88. Georgiou, M.C.; Bonanos, A.M.; Georgiadis, J.G. Evaluation of a solar powered distillation unit as a mitigation to water scarcity and climate change in Cyprus. Desalin. Water Treat. 2014, 52. [CrossRef]

89. Vidican, G.; Houdret, A. Energy and Water for MENA: From Risks to Opportunities. Available online: https://www.die-gdi.de/en/the-current-column/article/energy-and-water-for-mena-from-risks-toopportunities/ (accessed on 21 September 2018).

(C) 2019 by the author. Licensee MDPI, Basel, Switzerland. This article is an open access article distributed under the terms and conditions of the Creative Commons Attribution (CC BY) license (http://creativecommons.org/licenses/by/4.0/). 